\title{
Characteristic of Soil Moisture in Indonesia Using ESA CCI Satellites Products
}

\author{
Fatkhuroyan, Trinah Wati and Roni Kurniawan \\ Indonesia Agency for Meteorology Climatology and Geophysics, BMKG, Kemayoran, Central Jakarta, Indonesia
}

Received: 2019-03-13 Accepted: 2021-04-03

\begin{abstract}
Keywords:
Soil Moisture;

Indonesia;

ESA CCI;

Monthly;

Seasonal
\end{abstract}

Correspondent email:

fatkhuroyan@bmkg.go.id

\begin{abstract}
Soil moisture (SM) is one of the energy and water exchange main drivers between the atmosphere and land surface. The study aims to analyze the soil moisture characteristics in Indonesia on monthly and seasonal time scales. The analysis uses mapping of monthly and seasonal ESA CCI SM satellite products of mean daily from 1979 to 2016 . The results showed the spatial and temporal variability of SM in Indonesia. Sumatera has SM values $>0.3 \mathrm{~m}^{3} / \mathrm{m}^{3}$ almost throughout the year. Other than that, Java has SM values $>0.3 \mathrm{~m}^{3} / \mathrm{m}^{3}$ from January to April and October to December while $0.2-0.3 \mathrm{~m}^{3} / \mathrm{m}^{3}$ from May to September. In Borneo, the $S M$ value $>0.3 \mathrm{~m}^{3} / \mathrm{m}^{3}$ from February to June and November to December, while from July to September are $0.2-0.3 \mathrm{~m}^{3} / \mathrm{m}^{3}$. Sulawesi has SM values $>0.3 \mathrm{~m}^{3} / \mathrm{m}^{3}$ from January to July, on December, and $0.2-0.3 \mathrm{~m}^{3} / \mathrm{m}^{3}$ from august to November. Bali to Nusa Tenggara have SM values between 0.2$0.3 \mathrm{~m}^{3} / \mathrm{m}^{3}$ throughout the year, except $<0.2 \mathrm{~m}^{3} / \mathrm{m}^{3}$ in Sumba, Timor Island, and Central Lombok from June to November. Maluku has SM values between $0.2-0.3 \mathrm{~m}^{3} / \mathrm{m}^{3}$ throughout the year, while Papua has SM values $>0.3 \mathrm{~m}^{3} / \mathrm{m}^{3}$ throughout the year, except in Jayawijaya Mountain and South Papua. The ESA CCI SM product is essential for monitoring SM in Indonesia.
\end{abstract}

๑2021 by the authors. Licensee Indonesian Journal of Geography, Indonesia.

This article is an open access article distributed under the terms and conditions of the Creative Commons

Attribution(CC BY NC) licensehttps://creativecommons.org/licenses/by-nc/4.0/.

\section{Introduction}

Soil moisture (SM) has a crucial role in the land surface system for studies of the regional water cycle, climate change, agricultural irrigation management, and environmental monitoring (Liang et al, 2014; Zhang et al, 2015, El Hajj et al, 2016). SM is climate, hydrology, ecology, and agricultural variable influencing land-atmosphere interaction, affecting rainfall-runoff processes, regulating net ecosystem exchange, and constraining food security (Ochsner et al, 2013). SM is also one of the main drivers of the energy and water exchange between the atmosphere and land surface (Robinson et al, 2008). Additionally, SM can indicate water content sufficiency in vegetated environments due to the importance of water content for vegetation growth (Takagi et al, 2011). SM deals with the energy exchange between the atmosphere and land surface during evaporation. The vertical migration of SM influences the survival of vegetation.

Studies of SM estimation began in the 1960s because of the inadequacies of measurement equipment and theoretically immature. SM became an important parameter associated with other surface parameters for more comprehensive studies in the 1970s and 1980s (Idso et al, 1976; Carlson et al, 1981). Monitoring SM variability and change need high-quality SM datasets in length, continuity, and consistency both time and space (Loew, 2013; Findell et al., 2015). In-situ SM databases such as the International Soil Moisture Network (ISMN) provide detailed SM information (Dorigo et al., 2013; Ochsner et al., 2013) and ground-based observations for global coverage still inadequate for comprehensive Earth system assessments.
The development of remote sensing technology provides monitoring of SM for large areas using satellites. Since the late 1970s, satellite instruments can estimate and monitor the Spatio-temporal variations of regional SM. The development method in SM technologies includes COsmic-ray Soil Moisture Observing System (COSMOS), GPS-based techniques, and fiber-optic distributed temperature sensing (DTS) approaches (Larson et al., 2008; Sayde et al., 2010; Steele-Dunne et al., 2010; Zreda et al., 2008).

The Water Cycle Multi-mission Observation Strategy (WACMOS) project and the Climate Change Initiative (CCI) of the European Space Agency (ESA) released the first multisensor SM product for long time datasets (Liu et al., 2011; 2012; Wagner et al., 2012). This ESA CCI SM dataset builds upon the merging of different active (radar) and passive (radiometer) microwave instrument observations into a single consistent product (Dorigo et al., 2015) based on uncertainty information of the individual SM products (Dorigo et al., 2010). Variety studies were using ESA CCI SM datasets (Dorigo and de Jeu, 2016). The previous study by Rahmani et al. (2016) analyzed the performance of ESA CCI SM observations datasets over Iran to assess agricultural drought events. Zheng (2016) studied the spatial and temporal variations of SM change in Northeast China over the past 30 years and found a decreasing trend over time.

Measurements of SM in Indonesia are not available yet in most parts of Indonesia and still lack sufficient temporal and spatial resolution. Hence, the implementation of remote sensing SM products can derive SM information in Indonesia 
considering its global coverage and accuracy. This study objective is to analyze the soil moisture characteristics in Indonesia on monthly and seasonal time scales.

\section{Method}

SM of a soil $(\theta)$ is defined as the volume of water $V_{w}$ which can be removed from a volume of soil $\left(\mathrm{V}_{\mathrm{s}}\right)$ by drying the soil at $105^{\circ} \mathrm{C}$ :

$$
\theta=V_{\mathrm{w}} / \mathrm{V}_{\mathrm{s}}\left[\mathrm{m}^{3} / \mathrm{m}^{3}\right]
$$

The measurement of SM consists of in situ such as gravimetric method and based on the high relative permittivity. The other is satellite-derived SM that also relies on the high water relative permittivity in comparison to stone or air. The satellite-derived based SM dataset generated in the support of the ESA CCI program on the global observing of Essential Climate Variables (ECV) (Hollmann, 2013). It has daily temporal resolution, with $0.25^{\circ}$ spatial resolution, and units of $\mathrm{m}^{3} / \mathrm{m}^{3}$ (Liu et al., 2011, Liu et al., 2012, Wagner et al., 2012, Dorigo et al., 2015). Recently, the number of available satellites has escalated, which in turn improved data availability and data quality (Dorigo et al., 2015, Dorigo et al., 2010). The involved SM products are derived from Scanning Special Sensor Microwave/Imager (SSM/I), Multichannel Microwave Radiometer (SMMR), Tropical Rainfall Measuring Missions (TRMM) Microwave Imager (TMI), ASMR-E, ASCAT and Scatterometers (SCAT). The CCI SM has three products which differ in the data sources used namely passive microwave only, active microwave only, and merged passive-active product. In this study, the analysis of SM uses the merged passive-active product (version 04.2) during period of January 1979 to December 2016.

The monthly soil moisture each year is the average of daily ESA CCI SM data. The SM of each month is also being averaged to produce the 38 years (1979-2016) monthly mean map. Seasonal characteristics of soil moisture are the average during December-January-February (DJF), March-AprilMay (MAM), June-July-August (JJA), and SeptemberOctober-November (SON). The wet season in Indonesia happens from November to March and the dry season from May to September (Aldrian and Susanto, 2003).

\section{Result and Discussion}

\section{Spatial Distribution of Monthly Soil Moisture}

Statistically, the average of monthly SM di Indonesia is $0.2 \mathrm{~m}^{3} / \mathrm{m}^{3}$ in almost all months except in January to March which is $0.3 \mathrm{~m} 3 / \mathrm{m} 3$. The ranges of SM are from 0.1 to $0.5 \mathrm{~m}^{3} /$ $\mathrm{m}^{3}$ with a variance of $0.1 \mathrm{~m}^{3} / \mathrm{m}^{3}$. Evaluation of ESA SM CCI products using ground-based observations in the previous study has been conducted with absolutes values of 0.46 and the soil moisture anomalies are 0.36 using the average Spearman correlation coefficient (Dorigo et al., 2015). However, Indonesian territory was not included in the analysis because of the inadequacy of ground-based observation data. The spatial distribution of SM monthly mean values in Indonesia is presented in the figure 1 and seasonally in Figure 2.

Figurela shows the spatial distribution of soil moisture in January, most of the values are more than $0.3 \mathrm{~m}^{3} / \mathrm{m}^{3}$ (green) around Indonesia. Some areas in Sumatera (West Aceh, North Sumatera, East Riau, Southeast Sumatera, Bangka Belitung until Lampung), Jakarta, Southern part of Borneo, Eastern part of Bali, Lombok island, Western part of Sumbawa island, Sumba and Timor Island, Halmahera island, Buru island, Western part of Seram island, Jayawijaya mountain and Southern part of Papua have the values between $0.2-0.3 \mathrm{~m}^{3} / \mathrm{m}^{3}$ Yellow). Meanwhile, in February the yellow area $\left(0.2-0.3 \mathrm{~m}^{3} / \mathrm{m}^{3}\right)$ enlarges in North Sumatera, Riau and Central Borneo, while the green area $\left(>0.3 \mathrm{~m}^{3} / \mathrm{m}^{3}\right)$ enlarges in Lombok, Timor island and Papua (Figure $1 \mathrm{~b}$ in details).

In March, the yellow area $\left(0.2-0.3 \mathrm{~m}^{3} / \mathrm{m}^{3}\right)$ decrease in North Sumatera, Riau, South Sumatera, Central Borneo and Southern part of Papua, while in Medan, North Sumatera the values are $<0.2 \mathrm{~m}^{3} / \mathrm{m}^{3}$ (red color). The yellow area $(0.2-0.3$ $\mathrm{m}^{3} / \mathrm{m}^{3}$ ) increase in Bali, Lombok, Flores, Timor, Sulawesi, Buru island respectively (Figure 1c). In April as seen in Figure 1d, the green area $\left(>0.3 \mathrm{~m}^{3} / \mathrm{m}^{3}\right)$ enlarges in most part of Indonesia, especially in North Sumatera, Riau, South Sumatera, Central Borneo, Sulawesi, Buru island and Central Papua, while the yellow area $\left(0.2-0.3 \mathrm{~m}^{3} / \mathrm{m}^{3}\right)$ enlarges in Flores island.

The green area in May $\left(>0.3 \mathrm{~m}^{3} / \mathrm{m}^{3}\right)$ are mostly in all part of Indonesia, especially in North Sumatera, Riau, South Sumatera, Central Borneo, Sulawesi, Buru Island and Central Papua, while the yellow area $\left(0.2-0.3 \mathrm{~m}^{3} / \mathrm{m}^{3}\right)$ enlarges in around Jakarta, East Java and Flores Island (Figure 1e in details). In June, the yellow area $\left(0.2-0.3 \mathrm{~m}^{3} / \mathrm{m}^{3}\right)$ enlarge in Riau, South Sumatera, Borneo, Flores island, while the green area $\left(>0.3 \mathrm{~m}^{3} / \mathrm{m}^{3}\right)$ are in Central Papua and Maluku. Furthermore, The red area $\left(<0.2 \mathrm{~m}^{3} / \mathrm{m}^{3}\right)$ are in Sumba Island (Figure $1 \mathrm{f}$ in details).

In July, the yellow area $\left(0.2-0.3 \mathrm{~m}^{3} / \mathrm{m}^{3}\right)$ are in Sumatera, Borneo, west Java and east Java continue, while the green area $\left(>0.3 \mathrm{~m}^{3} / \mathrm{m}^{3}\right)$ enlarge in central Papua. Moreover, the red area $\left(<0.2 \mathrm{~m}^{3} / \mathrm{m}^{3}\right)$ also increase at Sumba island (Figure $1 \mathrm{~g}$ ). In August, the yellow area $\left(0.2-0.3 \mathrm{~m}^{3} / \mathrm{m}^{3}\right)$ continue to enlarge in Sumatera, Borneo, Java and Halmahera island, while the red area $\left(<0.2 \mathrm{~m}^{3} / \mathrm{m}^{3}\right)$ island also enlarge in Sumba and Timor (Figure 1h). In September, the yellow area (0.2-0.3 $\mathrm{m}^{3} / \mathrm{m}^{3}$ ) enlarge in Borneo, Java, Sulawesi and Buru island, while the green area $\left(<0.3 \mathrm{~m}^{3} / \mathrm{m}^{3}\right)$ enlarge in Riau. Futhermore, The red area $\left(<0.2 \mathrm{~m}^{3} / \mathrm{m}^{3}\right)$ increase in Timor and Sumbawa island (Figure $1 \mathrm{~h}$ and $1 \mathrm{i}$ ).

In October (Figure $1 \mathrm{j}$ ), the green area $\left(>0.3 \mathrm{~m}^{3} / \mathrm{m}^{3}\right)$ enlarge in Riau, south Sumatera, west Borneo, west and central Java, while the yellow area $\left(0.2-0.3 \mathrm{~m}^{3} / \mathrm{m}^{3}\right)$ increase in Sumbawa, Sulawesi, Seram Island and Papua. In November, the green area $\left(>0.3 \mathrm{~m}^{3} / \mathrm{m}^{3}\right)$ enlarge mostly in Sumatera, Borneo, Java, and Sulawesi enlarge, while the yellow area $\left(0.2-0.3 \mathrm{~m}^{3} / \mathrm{m}^{3}\right)$ in Sumba and Timor islands is increasing (Figure $1 \mathrm{k}$ in details). In December, the green area $\left(>0.3 \mathrm{~m}^{3} /\right.$ $\mathrm{m}^{3}$ ) continue to enlarge in most of Sumatera, Borneo, Java, and Sulawesi, Lombok and Flores, while the yellow area $(0.2$ $-0.3 \mathrm{~m}^{3} / \mathrm{m}^{3}$ ) increase in Sumba and Timor islands (Figure 11 in details).

\section{Spatial Distribution of Seasonal Soil Moisture}

The average of seasonal SM di Indonesia is $0.2 \mathrm{~m}^{3} / \mathrm{m}^{3}$ in MAM, JJA and SON, while during DJF is $0.3 \mathrm{~m}^{3} / \mathrm{m}^{3}$. Meanwhile, during the wet season the average is $0.3 \mathrm{~m}^{3} / \mathrm{m}^{3}$ dan the dry season is $0.2 \mathrm{~m}^{3} / \mathrm{m}^{3}$. Seasonal soil moisture distribution in Indonesia is presented in Figure 2. In the rainy season on DJF as seen in Figure. 2a, generally, the green area $\left(>0.3 \mathrm{~m}^{3} / \mathrm{m}^{3}\right)$ cover mostly all part of Indonesia. While the yellow area $\left(0.2-0.3 \mathrm{~m}^{3} / \mathrm{m}^{3}\right)$ cover some in Eastern part of Sumatera such as Riau, Bangka-Belitung, and South 


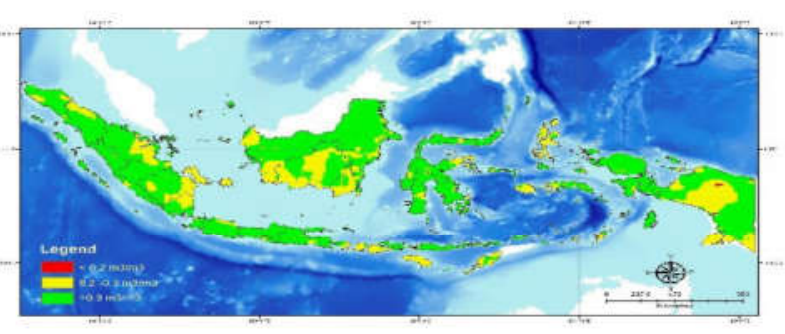

(a)

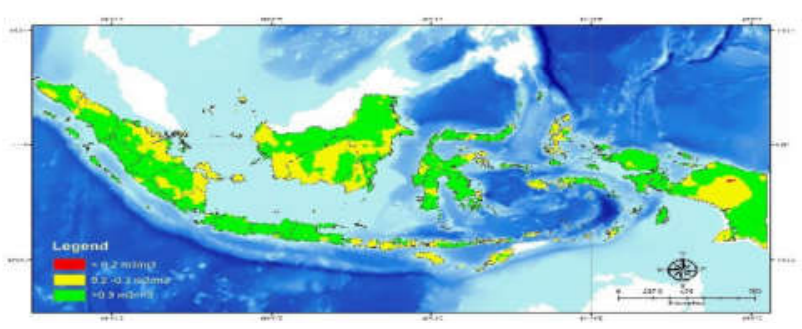

(c)

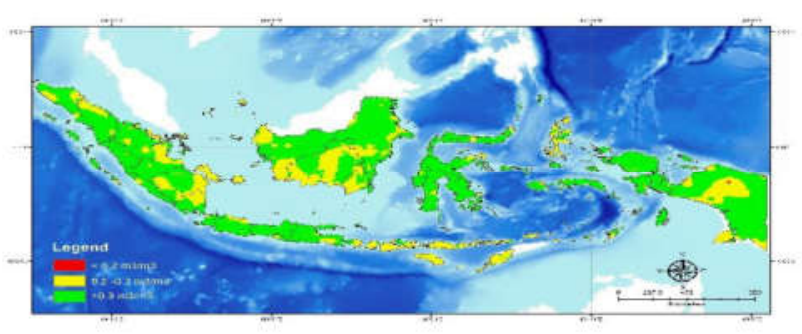

(e)

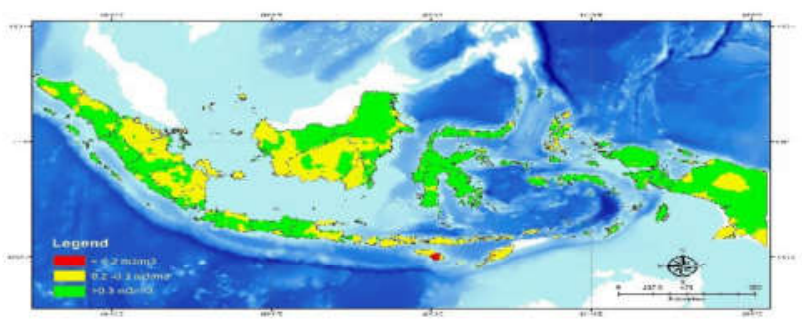

(g)

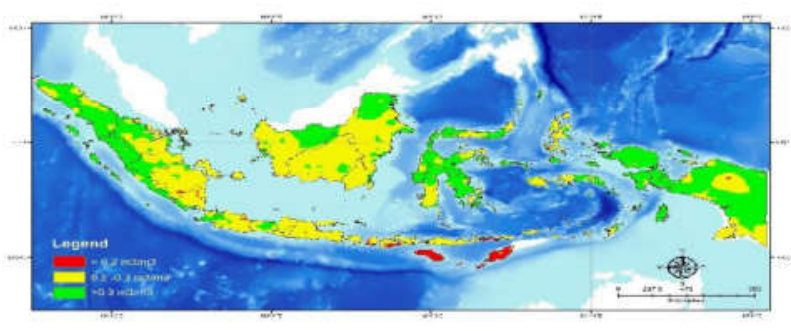

(i)

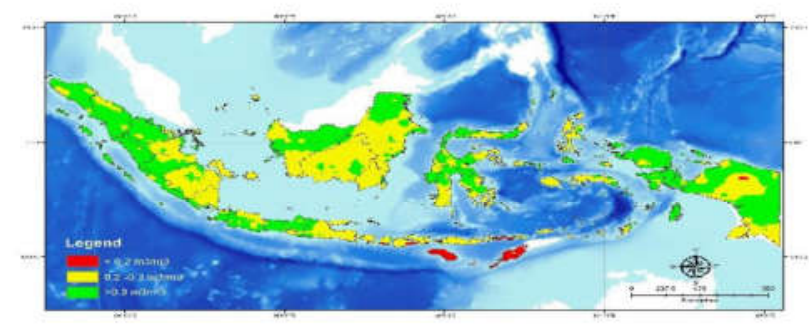

(k)

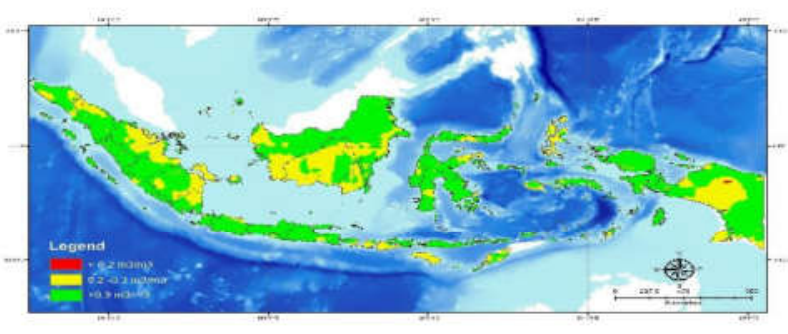

(b)

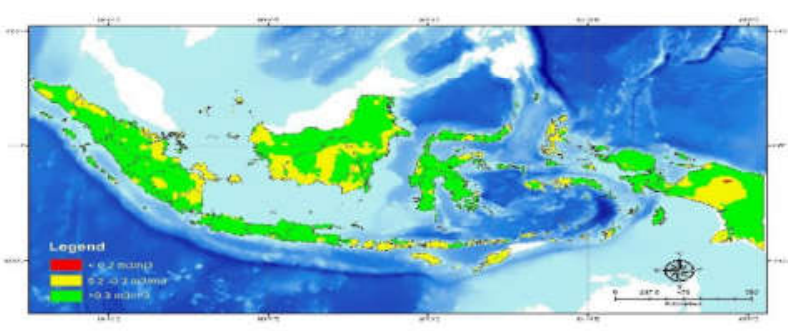

(d)

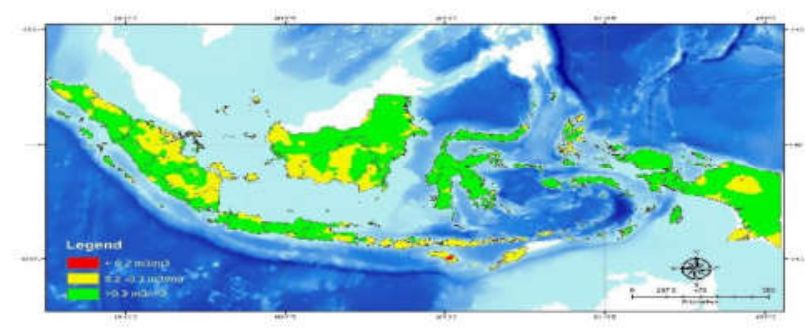

(f)

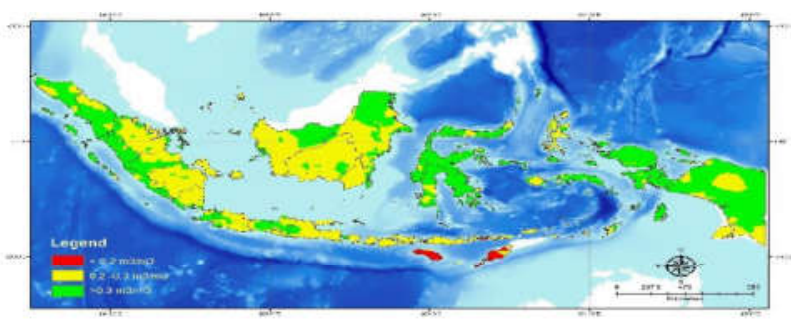

( h )

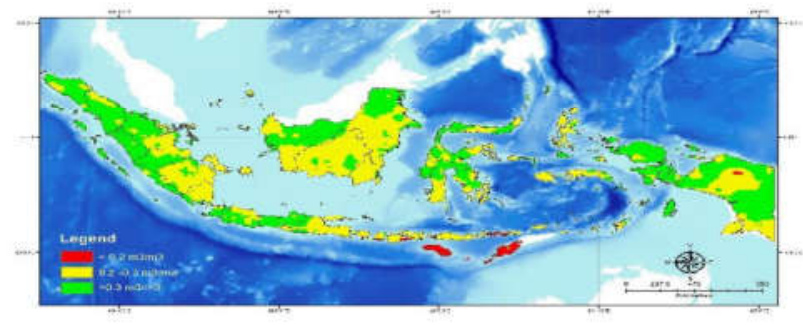

(j)

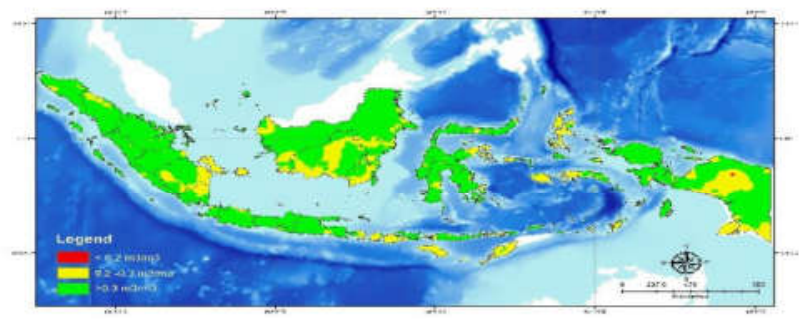

(I)

Figure 1. Monthly Soil Moisture Distribution in (a) January (b) February (c) March (d) April (e) May (f) June (g) July (h) August (i) September (j) October (k) November (l) December in Indonesia 
Sumatera. It also cover some parts in Central Borneo, Nusa Tenggara, Halmahera, Buru island, some part of Papua, especially in Jayawijaya mountain and Southern Papua.

In The transition season on MAM as seen in Figure $2 b$, the yellow area $\left(0.2-0.3 \mathrm{~m}^{3} / \mathrm{m}^{3}\right)$ increase in North Sumatera, Riau, Central Borneo, Flores, and Timor island, while the green area $\left(>0.3 \mathrm{~m}^{3} / \mathrm{m}^{3}\right)$ increase in Buru island and central Papua increase. In the dry season on JJA as seen in Figure. $2 \mathrm{c}$, the yellow area $\left(0.2-0.3 \mathrm{~m}^{3} / \mathrm{m}^{3}\right)$ continue to enlarge in Western part of Indonesia such as Sumatera, Borneo, Java, Bali, Nusa Tenggara, while the green area $\left(>0.3 \mathrm{~m}^{3} / \mathrm{m}^{3}\right)$ increase in Eastern part of Indonesia such as Sulawesi, Maluku and Papua. Moreover, there are small red area $(<0.2$ $\left.\mathrm{m}^{3} / \mathrm{m}^{3}\right)$ in Sumba island. In The transition season on SON as seen in Figure 2d, the yellow area $\left(0.2-0.3 \mathrm{~m}^{3} / \mathrm{m}^{3}\right)$ enlarge in Borneo, East Java, Sulawesi, Maluku and Papua, while the green area $\left(>0.3 \mathrm{~m}^{3} / \mathrm{m}^{3}\right)$ increase only in North Sumatera and Riau. Moreover, the red area $\left(<0.2 \mathrm{~m}^{3} / \mathrm{m}^{3}\right)$ enlarge in Sumba, Timor and Lombok.

The variability of soil moisture is influenced by precipitation and evapotranspiration according to time duration as the main driver of soil moisture variability. The function of topography, vegetation, soil characteristics, and groundwater also influence the temporal variability of SM (Porporato et al, 2004; Riley and Shen, 2014; Rosenbaum et al, 2002; Brocca et al, 2017). The impact of SM in the climate system includes interaction between SM with evapotranspiration, precipitation, and temperature. Evapotranspiration has main role in the transportation of water from land (transpiration of plant and evaporation of bare soil) to the atmosphere which impacts the SM. The

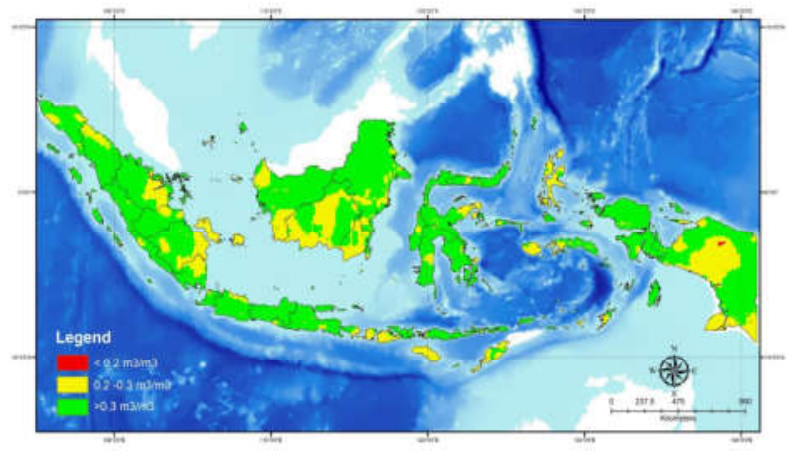

(a)

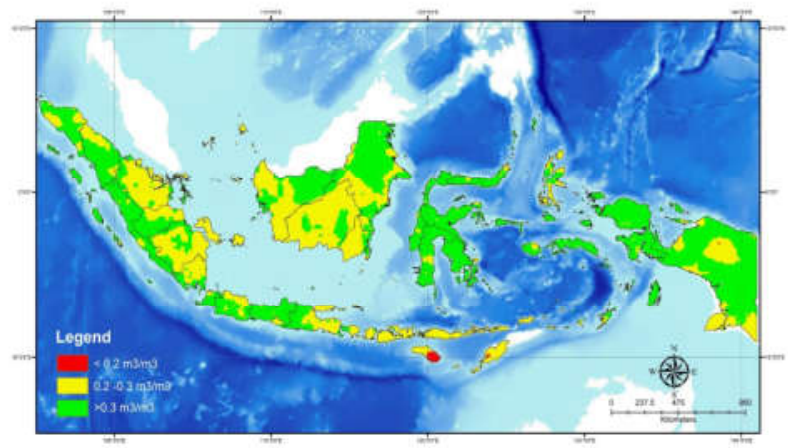

(c) increasing of temperature leads to more evaporative demand and further drying of soil or decreasing of SM. The increasing of precipitation/rainfall leads to higher SM except for some cases in arid regions and runoff anomalies (Seneviratne et al, 2010).

We studied the evidence from observation of rainfall and temperature for coupling with ESA CCI SM in some stations of Indonesia. We choose the stations which represent the type of rainfall in Indonesia. Indonesia has three types of rainfall (Aldrian and Susanto, 2003). The monsun type are Tanjung Priok (Java) and Ngurah Rai (Bali) Stations, equatorial type are Pekanbaru (Sumatera), Palangkaraya (Borneo) and Biak (Papua) stations, while the local type is Luwuk station. The period of observation data is the same as the ESA CCI SM.

Figure 3 shows the monthly pattern of ESA CCI SM coupling with observation monthly rainfall. The pattern mostly similar except in Ngurah Rai, the decreasing of SM do not significantly dry with the lower rainfall in the dry season. The pattern of SM in Biak follows the rainfall around 1 month lag time. The variability of ESA CCI SM can capture the type of precipitation in Indonesia. Figure 4 shows the monthly pattern of ESA CCI SM coupling with observation monthly temperature. The pattern represents the higher temperature the lower SM in Tanjung Priok, Pekanbaru, Luwuk and Biak. Some stations such as Palangkaraya and Ngurah Rai show different patterns, the type of soil and water management system may influence the variability of SM in those locations. The previous study said that ESA CCI SM has good agreement generally with land surface models and observed in-situ in spatial and temporal patterns.

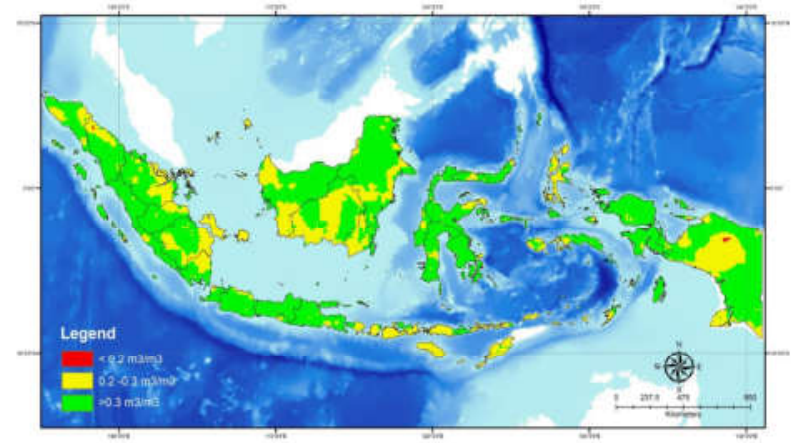

(b)

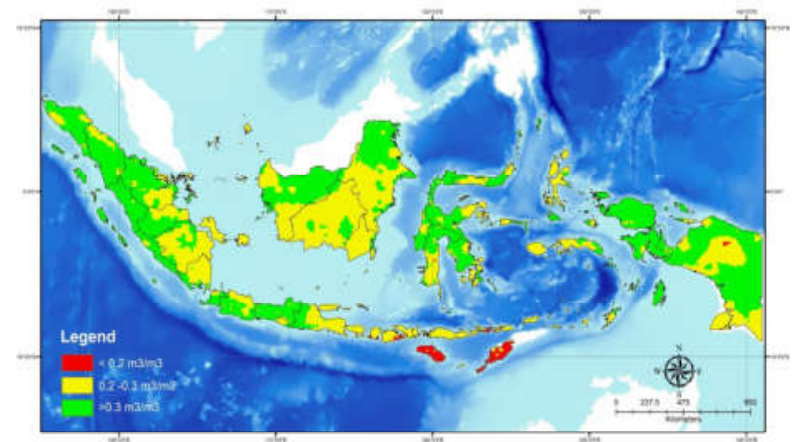

(d)

Figure 2. Seasonal Distribution of Soil Moisture in (a) DJF (b) MAM (c) JJA (d) SON 


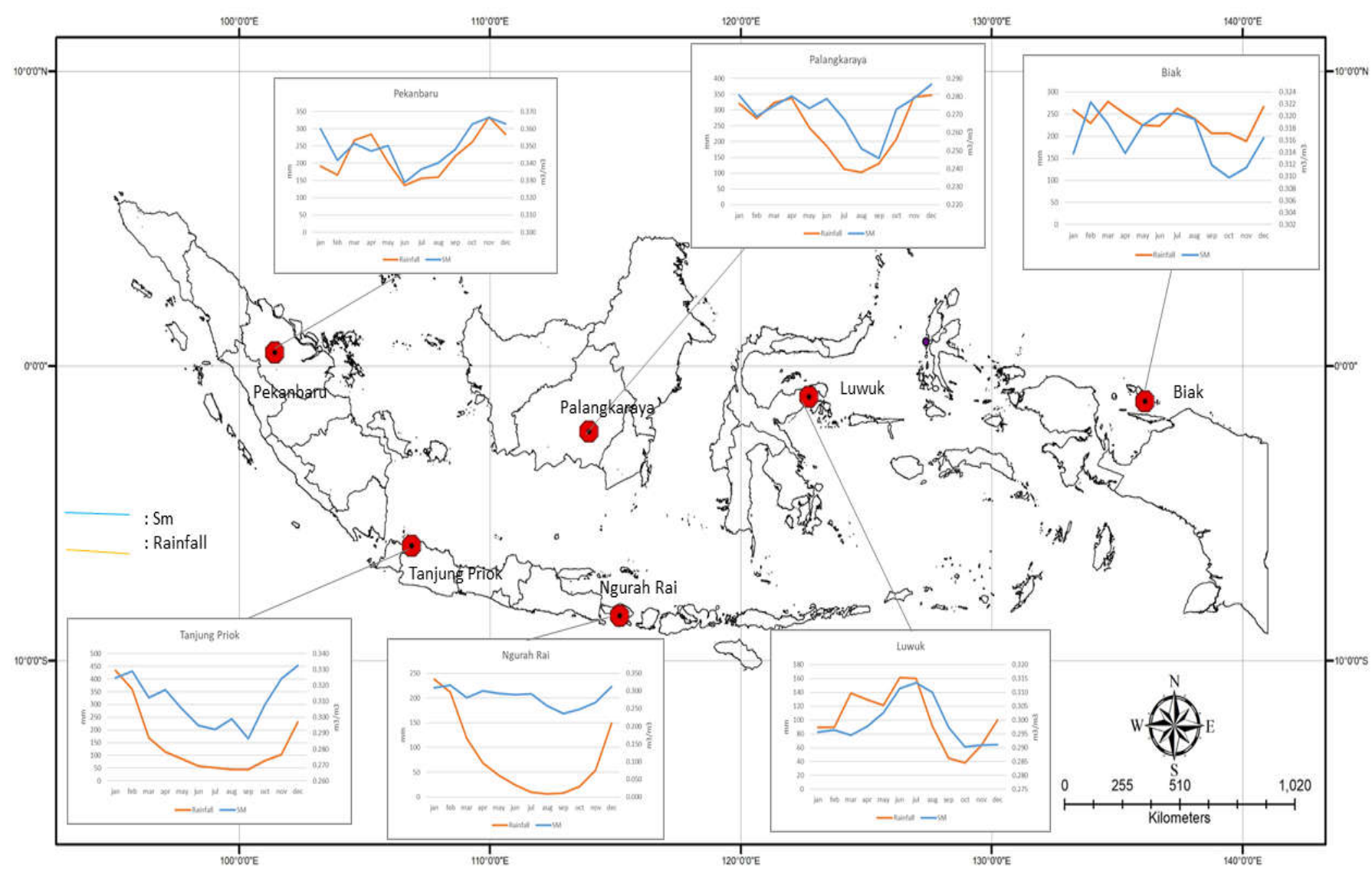

Figure 3. Coupling ESA CCI SM with observation rainfall

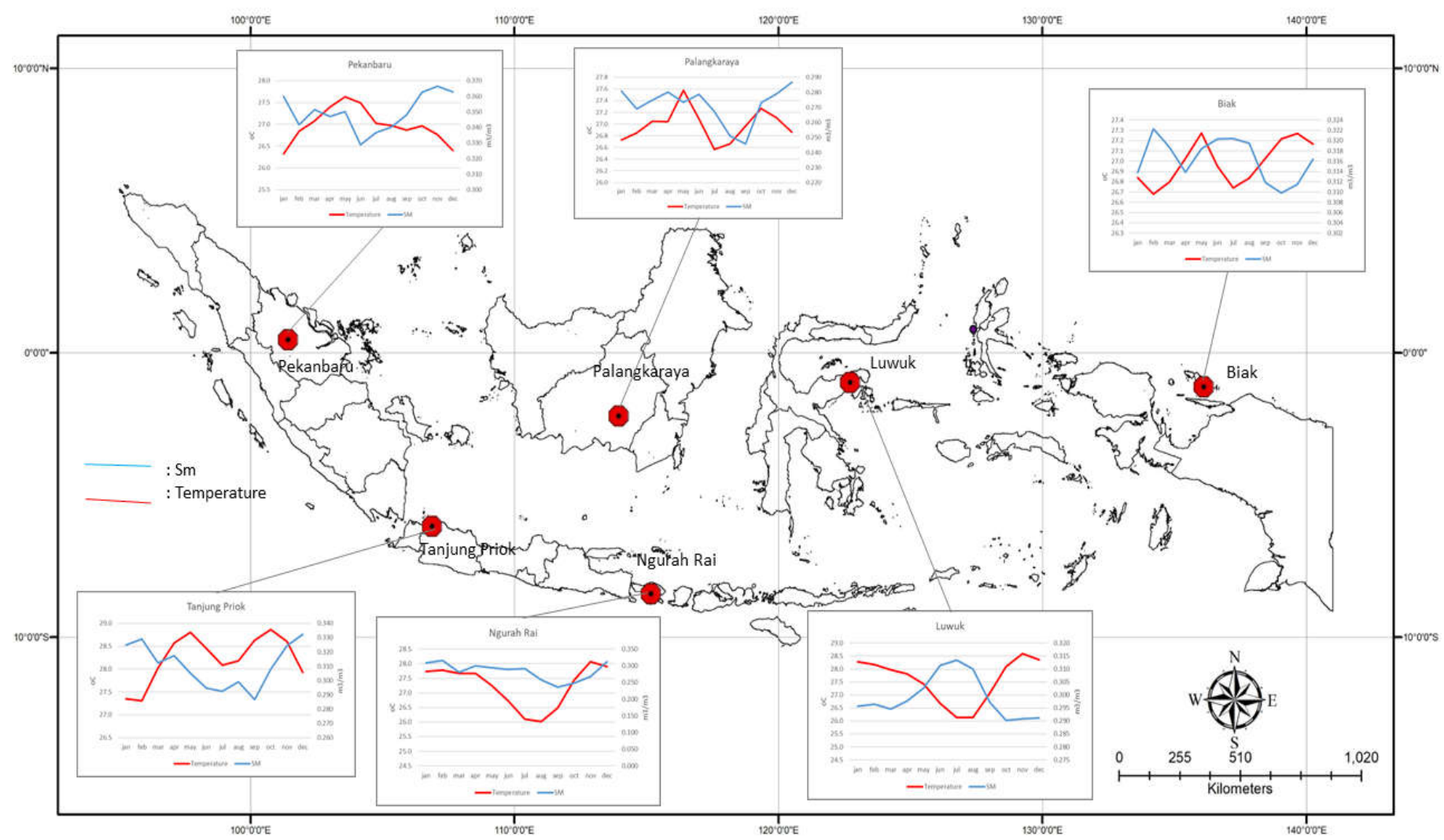

Figure 4. Coupling ESA CCI SM with observation temperature 
However, the uncertainties still remain according to surface conditions such as vegetation and organic soils (Dorigo et al, 2017).

\section{Conclusion}

Generally, SM in Sumatera and Papua have the values > $0.3 \mathrm{~m}^{3} / \mathrm{m}^{3}$ almost along the year, except in Jayawijaya mountain and South Papua. Meanwhile, the SM values in Java are $>0.3 \mathrm{~m}^{3} / \mathrm{m}^{3}$ from January to April, and from October to December. However, the SM values are between $0.2-0.3 \mathrm{~m}^{3} / \mathrm{m}^{3}$ for the other months. Borneo has the $\mathrm{SM}$ values $>0.3 \mathrm{~m}^{3} / \mathrm{m}^{3}$ from February to June, and November to December, while the SM values are between $0.2-0.3 \mathrm{~m}^{3} / \mathrm{m}^{3}$ for the other months. Sulawesi has the SM Values $>0.3 \mathrm{~m}^{3} / \mathrm{m}^{3}$ from January to July and December, while the SM values are between $0.2-0.3 \mathrm{~m}^{3} / \mathrm{m}^{3}$ from august to November. Moreover, Maluku, Bali, and Nusa Tenggara have SM values between $0.2-0.3 \mathrm{~m}^{3} / \mathrm{m}^{3}$ throughout the year, except in Sumba, Timor island, and Central Lombok.

The climatology of ESA CCI SM products mapping during 1979-2016 analyzes the characteristic of SM variability in monthly and seasonal time scales over Indonesia. The function of topography, vegetation, soil characteristics, and groundwater also influence the temporal variability of SM. Comparison between SM with observation precipitation shows positive feedback, while SM with observation temperature shows negative feedback. The spatial variability of SM can capture the type of precipitation in Indonesia. The implementation of the dataset can be used for monitoring the SM in Indonesia considering the limitation of SM groundbased observations.

\section{Acknowledgement}

We are grateful to the availability of the ECV soil moisture dataset from ESA website. All authors contributed equally to this work. All authors discussed the results, implications, and commented on the manuscripts at all stages.

\section{References}

Aldrian, E., \& Dwi Susanto, R. (2003). Identification of three dominant rainfall regions within Indonesia and their relationship to sea surface temperature. International Journal of Climatology: A Journal of the Royal Meteorological Society, 23 (12), 1435-1452.

Brocca, L., Ciabatta, L., Massari, C., Camici, S., \& Tarpanelli, A. (2017). Soil moisture for hydrological applications: Open questions and new opportunities. Water, 9(2), 140.

Carlson, T.N.; Dodd, J.K.; Benjamin, S.G.; Cooper, J.N. (1981). Satellite estimation of the surface energy balance, moisture availability and thermal inertia. J. Appl. Meteor. 1981, 20, 67-87.

Carlson, T.N. (1986). Regional-scale estimates of surface moisture availability and thermal inertia using remote thermal measurements. Remote Sens. Rev. 1986, 1, 197-247.

Chen, X.Z.; Chen, S.S.; Zhong, R.F.; Su, Y.X.; Liao, J.S.; Li, D.; Han, L.; Lia, Y.; Li, X. (2012). A semi-empirical inversion model for assessing surface soil moisture using AMSR-E brightness temperatures. J. Hydrol. 2012, 456, 1-11.

Dee, D.P., Uppala, S.M., Simmons, A.J., Berrisford, P., Poli, P., Kobayashi, S., Andrae, U., Balmaseda, M.A., Balsamo, G., Bauer, P., Bechtold, P., Beljaars, A.C.M., van de Berg, L., Bidlot, J., Bormann, N., Delsol, C., Dragani, R., Fuentes, M., Geer, A.J., Haimberger, L., Healy, S.B., Hersbach, H., Hólm, E.V., Isaksen, L., Kållberg, P., Köhler, M., Matricardi, M., McNally, A.P., Monge-Sanz, B.M., Morcrette, J.J., Park, B.K., Peubey, C., de Rosnay, P., Tavolato, C., Thépaut, J.N., Vitart, F. (2011). The
ERA-interim reanalysis: configuration and performance of the data assimilation system. Q. J. R. Meteorol. Soc. 137, 553-597.

Dorigo, W.A., Scipal, K., Parinussa, R.M., Liu, Y.Y., Wagner, W., de Jeu, R.A.M., Naeimi, V. (2010). Error characterisation of global active and passive microwave soil moisture data sets. Hydrol. Earth Syst. Sci. 14, 2605-2616.

Dorigo, W.A., Xaver, A., Vreugdenhil, M., Gruber, A., Hegyiová, A., Sanchis-Dufau, A.D., Wagner, W., Drusch, M. (2013). Global automated quality control of in-situ soil moisture data from the International Soil Moisture Network. Vadose Zone Journal. Vol. 12 , No.3.

Dorigo,W. A., Gruber, A., De Jeu, R. A. M.,Wagner,W., Stacke, T., Loew, A., Albergel, C., Brocca, L., Chung, D., Parinussa, R. M., and Kidd, R. (2015). Evaluation of the ESA CCI soil moisture product using ground-based observations. Remote Sens. Environ., 162, 380-395, doi:10.1016/j.rse.2014.07.023, 2015.

Dorigo, W., De Jeu, R. (2016). Satellite soil moisture for advancing our understanding of earth system processes and climate change. Int. J. Appl. Earth Obs. Geoinf. 48, 1-4.

Dorigo, W., Wagner, W., Albergel, C., Albrecht, F., Balsamo, G., Brocca, L., Chung, D., Ertl, M., Forkel, M., Gruber, A. and Haas, E., (2017). ESA CCI Soil Moisture for improved Earth system understanding: State-of-the art and future directions. Remote Sensing of Environment, 203, pp.185-215.

El Hajj, M.; Baghdadi, N.; Zribi, M.; Belaud, G. (2016). Soil moisture retrieval over irrigated grassland using X-band SAR data. Remote Sens. Environ. 2016, 176, 202-218.

Findell, K.L., Gentine, P., Lintner, B.R., Guillod, B.P. (2015). Data length requirements for observational estimates of landatmosphere coupling strength. J. Hydrometeorol. 16, 16151635.

Idso, S.B.; Jackson, R.D.; Reginato, R.J. (1976). Compensating for environmental variability in the thermal inertia approach to remote sensing of soil moisture. J. Appl. Meteor. 1976, 15, 811817

Larson, K.M., E.E. Small, E. Gutmann, A. Bilich, P. Axelrad, and J. Braun. (2008). Using GPS multipath to measure soil moisture fluctuations: Initial results. GPS Solut. 12:173-177. doi:10.1007/ s10291-007-0076-6

Liang, W.L.; Hung, F.X.; Chan, M.C.; Lu, T.H. (2014). Spatial structure of surface soil water content in a natural forested headwater catchment with a subtropical monsoon climate. J. Hydrol. 2014, 516, 210-221.

Liu, Y. Y., Parinussa, R. M., Dorigo, W. A., De Jeu, R. A. M., Wagner, W., van Dijk, A. I. J. M., McCabe, M. F., and Evans, J. P. (2011). Developing an improved soil moisture dataset by blending passive and active microwave satellite-based retrievals. Hydrol. Earth Syst. Sci., 15, 425-436, doi:10.5194/hess-15-4252011.

Liu, Y. Y., Dorigo, W. A., Parinussa, R. M., de Jeu, R. A. M., Wagner, W., McCabe, M. F., Evans, J. P., and van Dijk, A. I. J. M. (2012). Trend-preserving blending of passive and active microwave soil moisture retrievals. Remote Sens. Environ., 123, 280-297, doi:10.1016/j.rse.2012.03.014, 2012.

Loew, A. (2013). Terrestrial satellite records for climate studies: how long is long enough? A test case for the Sahel. Theor. Appl. Climatol. 115, 427-440.

Moran, M.S.; Clarke, T.R.; Inoue, Y.; Vidal, A. (1994). Estimating crop water deficit using the relation of between surface air temperature and spectral vegetation index. Remote Sens. Environ. 1994, 49, 246-263.

Ochsner, T.E., Cosh,M., Cuenca, R., Dorigo,W., Draper, C., Hagimoto, Y., Kerr, Y., Larson, K., Njoku, E., Small, E., Zreda, M. (2013). State of the art in large-scale soil moisture monitoring. Soil Sci. Soc. Am. J. 77.

Porporato, A.; Daly, E.; Rodriguez-Iturbe, I. (2004). Soil water balance and ecosystem response to climate change. Amer. Nat. Society. 2004, 164, 625-632.

Rahmani, A., Golian, S., \& Brocca, L. (2016). Multiyear monitoring of soil moisture over Iran through satellite and reanalysis soil 
moisture products. International Journal of Applied Earth Observation and Geoinformation, 48, 85-95. doi:10.1016/ j.jag.2015.06.009

Riley, W.J.; Shen, C. (2014). Characterizing coarse-resolution watershed soil moisture heterogeneity using fine-scale simulations. Hydrol. Earth Syst. Sci. 2014, 18, 2463-2483.

Robinson, D.A.; Campbell, C.S. (2008). Soil Moisture Measurement for Ecological and Hydrological Watershed-Scale Observatories: A Review. Vadose Zone Journal. 2008, 7, 358-389.

Rodell, M., Houser, P.R., Jambor, U., Gottschalck, J., Mitchell, K., Meng, C.J., Arsenault, K., Cosgrove, B., Radakovich, J., Bosilovich, M., Entin, J.K., Walker, J.P., Lohmann, D., Toll, D. (2004). The global land data assimilation system. Bull. Am. Meteorol. Soc. 85, 381-394.

Rodriguez-Iturbe, I.; D’Odorico, P.; Porporato, A.; Ridolfi, L. (1999). On the spatial and temporal links between vegetation, climate, and soil moisture. Water Resour. Res. 1999, 35, 37093722.

Rosenbaum, U.; Bogena, H.R.; Herbst, M.; Huisman, J.A.; Peterson, T.J.; Weuthen, A.;Western, A.; Vereecken, H. (2002). Seasonal and event dynamics of spatial soil moisture patterns at the small catchment scale.Water Resour. Res. 2002, 48, W10544.

Sandholt, I.; Rasmussen, K.; Andersen, J. (2002). A simple interpretation of the surface temperature/vegetation index space for assessment of surface moisture status. Remote Sens. Environ. 2002, 79, 213-224.

Sayde, C., C. Gregory, M. Gil-Rodriguez, N. Tufillaro, S. Tyler, N. van de Giesen, et al. (2010) . Feasibility of soil moisture monitoring with heated fiber optics. Water Resour. Res. 46:W06201. doi:10.1029/2009WR007846

Seneviratne, S.I., Corti, T., Davin, E.L., Hirschi, M., Jaeger, E.B., Lehner, I., Orlowsky, B. and Teuling, A.J., (2010). Investigating soil moisture-climate interactions in a changing climate: A review. Earth-Science Reviews, 99(3-4), pp.125-161.

Steele-Dunne, S.C., M.M. Rutten, D.M. Krzeminska, M. Hausner, S.W. Tyler, J. Selker, et al. (2010). Feasibility of soil moisture estimation using passive distributed temperature sensing. Water Resour. Res. 46:W03534. doi:10.1029/2009WR008272

Takagi, K.; Lin, H.S. (2011). Temporal dynamics of soil moisture spatial variability in the shale hills critical zone observatory. Vadose Zone Journal. 2011, 10, 832-842.

Yuan, X., Ma, Z., Pan, M., Shi, C.C.G.L. (2015). Microwave remote sensing of short-term droughts during crop growing seasons. Geophysical Research Letter. http:// dx.doi.org/10.1002/2015GL064125.

Ulaby, F.T.; Moore, R.K.; Fung, A.K. Microwave Remote Sensing: Active and Passive; Artech House Inc.: Dedham, MA, USA, 1986

Wagner, W., Dorigo, W., de Jeu, R., Fernandez, D., Benveniste, J., Haas, E., and Ertl, M. (2012). Fusion of active and passive microwave observations to create an essential climate variable data record on soil moisture, ISPRS Ann. Photogramm. Remote Sens. Spat. Inf. Sci., I-7, 315-321, doi:10.5194/isprsannals-I-7315-2012.

Zhang, D.; Li, Z.L.; Tang, R.; Tang, B.H.; Wu, H.; Lu, J.; Shao, K. (2015). Validation of a practical normalized soil moisture model with in situ measurements in humid and semi-arid regions. Int. J. Remote Sens. 2015, 36, 5015-5030.

Zheng, X., Zhao, K., Ding, Y., Jiang, T., Zhang, S., \& Jin, M. (2016). The spatiotemporal patterns of surface soil moisture in Northeast China based on remote sensing products. Journal of Water and Climate Change, 7(4), 708-720. doi:10.2166/ wcc.2016.106

Zreda, M., D. Desilets, T.P.A. Ferré, and R.L. Scott. (2008). Measuring soil moisture content non-invasively at intermediate spatial scale using cosmic-ray neutrons. Geophys. Res. Lett. 35:L21402. doi:10.1029/2008GL035655 